\title{
What drives firm profitability? A comparison of the US and EU food processing industry
}

Abstract: This article analyzes persistence and the drivers of profitability in US and EU food processing using GMM estimations. Due to different firm size structures first comparable samples of US and EU food processors are derived using Propensity Score Matching. The GMM results indicate that profit persistence in food processing is lower than in other manufacturing sectors. Firm-specific drivers of profitability are size and financial risk. Regarding industry characteristics concentration and the growth rate significantly influence profitability. The findings provide insights for the management of food processing firms as well as for policy decisions aiming to enhance the competitiveness of firms in the food processing sector.

Keywords: Firm profits, persistence, food industry, GMM panel estimation, propensity score matching.

\section{Introduction}

The analysis of firm profits that diverge from the competitive profit rate is one of the pivotal fields of study within economic research (e.g. Porter 1980; Barney 1991; McGahan and Porter 2003; Hirsch and Gschwandtner 2013).

From a theoretical point of view the neoclassical model of perfect competition postulates that firm profits above or below the competitive norm cannot persist in the long run as such profits are immediately driven back to the norm by competitive forces (e.g. Carlton and Perloff 2005). Nevertheless, in the real world, profits that diverge from the competitive norm are, despite declining trade barriers, a rather usual phenomenon for many industrial markets.

Starting with the contributions of Mueller $(1986,1990)$ many empirical studies have shown that industries are in general characterized by a large number of firms generating profits that diverge from the competitive norm in the long run -a phenomenon usually referred to as profit persistence. The majority of those studies either considers entire economies or is restricted to firms operating in manufacturing sectors of specific countries. Some important studies on profit persistence include: Waring (1996), Wiggins and Ruefli (2002), Chacar and Vissa (2005), and Gschwandtner (2005), for the US manufacturing sector; Glen et al. (2001) for 7 developing countries; Goddard et al., (2005), Bou and Satorra (2007), Pattitoni et al. (2014), and Gallizo et al. (2014) for the EU manufacturing and service sector.

While most previous studies on food industry performance, focus on more specific aspects such as the impact of retailer concentration on industry innovation (Weiss and Wittkopp 2005) 
or the influence of diversification strategies on profit (Dorsey and Boland 2009) as yet, only a few studies have explicitly analyzed the persistence and drivers of profits deviating from the norm in the food sector. For the US food economy Schumacher and Boland (2005) using variance decomposition methods find that industry effects are more important for profit persistence than corporate effects. Nevertheless, Schumacher and Boland (2005) do not quantify the firm and industry characteristics (such as firm size or industry concentration) which determine the extent of profits deviating from the norm. Chaddad and Mondelli (2013) apply hierarchical linear modeling (HLM) to the US food economy to determine the impact of industry and firm effects as well as those structural factors that affect the performance of firms. They find that firm effects outweigh industry effects and that structural firm- and industry variables such as corporate $R \& D$ intensity and industry capital intensity are significant drivers of firm profits. Hirsch et al. (2014) apply HLM to the EU food processing industry. Their results also provide evidence for dominant firm effects. Furthermore, firm size and industry concentration are identified as drivers of performance. However, the HLM approach is of static nature and not suitable to capture the dynamics of firm profits over time. Nevertheless, it can be assumed that the conditional probability that a firm will achieve a specific degree of profits deviating from the norm in the future is a dynamic function of deviating profits in the past (e.g. Hsiao 2007; Baltagi 2008). Due to this reason Hirsch and Gschwandtner (2013) implement a dynamic panel model to a large panel of EU food processors over the period 1996-2008. They show that due to high market saturation and strong bargaining pressure from the retail sector the persistence of profits deviating from the norm in the EU food processing industry is significantly lower compared to other manufacturing sectors. As the main profit driver they identify firm size as besides economies of scale larger firms are in a better bargaining position against retailers.

In summary as yet no study exists that estimates the degree of profit persistence as well as the drivers of profits deviating from the norm in the US food sector based on a dynamic approach. This is important as profits and profit persistence are changing over time. Our primary objective is therefore to provide evidence on the drivers and persistence of firm profits deviating from the norm in the US food processing industry by analyzing a sample of 104 publicly quoted US food processors over the time span 1996-2014. Moreover, we aim to compare the US results to a matched sample of EU food processing firms. We advance the literature by first applying propensity score matching (PSM) in order to derive a sample of EU firms which is comparable to the US sample. This is necessary due to significant structural differences between the US and EU food processing industry -in particular regarding firm size 
as well as poor data availability for small-scale firms in the US. In addition to avoid biases in the comparison of US and EU food processors we assess in how far firms in the analyzed samples are affected by industry specific events such as M\&A waves, the economic crisis or ownership structure.

Subsequently, we apply the GMM dynamic panel estimator to the US and the matched EU panel to determine the extent of profit persistence as well as those factors that have an impact on firm profits deviating from the norm. The US results are the first of this kind and we identify significant differences to the results of the matched EU panel. These differences may have important management and policy implications.

In the next section we present the theoretical background based on which the drivers of firm profitability are identified. Subsequently the econometrics used to match the US and EU panel and to estimate the persistence and drivers of firm profits deviating from the norm are described. We then provide a comparison of US and EU food processing as well as a description of the data. This is followed by the discussion of the empirical results. Finally, conclusions are drawn and implications derived.

\section{Theoretical background}

Classical industrial organization theory and in particular the structure-conduct-performance (SCP) paradigm assumes that industry characteristics which determine the extent of entry barriers and competition are the main determinant of firm performance. Among those characteristics are the degree of concentration as well as the size and growth rate of an industry (Bain 1956, 1968; Porter 1980). While the SCP has been heavily criticized for its assumption of a direct impact of industry structure on profitability (e.g. Tirole 1988) the Market-Based View (MBV), as a dynamic extension of the SCP, additionally considers the strategic positioning of firms within the industry (Welge and Al-Laham 2008). Consequently, besides industry structure strategic management literature stresses the importance of business-specific resources as determinants of profitability (Goddard et al. 2005). According to Penrose (1959) firms are to be interpreted as bundles of physical and intangible resources. Divergence of performance between firms, emerges due to differences in endowment with those resources. According to the resource based view (RBV), firms endowed with specific valuable, rare and inimitable resources are more competitive and hence outperform the market (Barney 1991; Peteraf 1993). Those resources include tangible i.e. financial and physical factors of production as well as intangible factors such as technology and reputation (Claver et al. 2002; Goddard et 
al. 2005). When estimating the impact of firm specific resources in particular firm size, market share, growth, age, advertising, $\mathrm{R} \& \mathrm{D}$, patents and financial risk have been identified as empirical determinants by previous literature (e.g. Yurtoglu 2004; Chaddad and Mondelli, 2013).

In the 1980's a supplementary strand of research known as 'New Empirical Industrial Organization' literature (NEIO) has emerged (e.g. Bresnahan, 1981). NEIO studies model the strategic and competitive behavior of firms on the basis of game theory and structural econometric approaches. Those models enable to consider more detailed industry- and firmspecific factors than what modeling based on the MBV and the RBV can capture. Among those factors are demand structures, cost advantages and collusive behavior that decreases competition. However, while NEIO provides a useful background for case studies, as it allows for a detailed modeling of specific sub-industries (e.g. dairy processing or meat processing), we aim to provide generalizable insights of profitability across food industries based on the structural relationships suggested by the MBV and the RBV. (Kadiyali et al., 2001)

\section{Methodology}

We first employ PSM, a method commonly applied in observational studies to eliminate selection biases, to construct an EU sample that matches the 104 publicly quoted US firms (Huang et al. 2013). Afterwards, we quantify profit persistence as well as the factors that have an influence on the degree of firm profits deviating from the norm for both samples.

\subsection{Propensity Score Matching}

PSM is commonly applied in observational studies to eliminate selection biases that arise if observations are not randomly assigned to receive a specific treatment (Heinrich et al. 2010). The main objective of PSM is to match an untreated group to a group that receives a specific treatment such that the observations of the untreated group can be compared to those of the treated group regarding all attributes except for the treatment (Huang et al. 2013). ${ }^{1}$

In general, PSM can be applied to settings where a treatment (e.g. medication, labor market policy, agricultural policy intervention) is given to a specific group of individuals. The majority of research focuses on the outcome of the treatment, referred to as the 'average treatment effect

\footnotetext{
${ }^{1}$ PSM has been employed in diverse fields of study such as the evaluation of labor market policies (e.g. Dehejia and Wahba 1999), or medical and pharmacoepidemiological research (e.g. Perkins et al. 2000; Austin 2008) as well as the agribusiness sector (Cavatassi et al. 2011; Bontemps et al. 2013; Key and McBride 2014) (Caliendo and Kopeining 2005).
} 
on the treated (ATT)', by comparing the treated sample with a constructed matched sample of untreated observations. Algebraically the ATT can be defined as:

$$
A T T=E[Y(1) \mid D=1]-E[Y(0) \mid D=1] \text {, }
$$

where $Y(D)$ is either the outcome of an observation that has been treated (if $D=1$ ) or of an observation that has not been exposed to treatment (if $D=0$ ). Thus, the first conditional expectation in (1) refers to the mean outcome of the treatment across observations in the treated group while the second one indicates the mean outcome of observations in the treated group assuming that they did not receive treatment. However as $E[Y(0) \mid D=1]$ is not observable a suitable substitute has to be constructed. Simply using the mean outcome value across all untreated observations $E[Y(0) \mid D=0]$ leads to biased results as observations are not randomly assigned to treated and untreated groups. Thus, those factors $(X)$ which have an impact on the likelihood of receiving treatment also have an impact on the treatment outcome (Caliendo and Kopeining 2005; Briggeman et al. 2009). One possible approach to construct a suitable proxy for $E[Y(0) \mid D=1]$ is to use a balancing score $P(D=1 \mid X)=P(X)$ which indicates the probability that an observation receives treatment, given the covariates $X$ (Heckman et al. 1997; Caliendo and Kopeining 2005). $P(X)$ is usually referred to as an observation's Propensity Score (PS) (Rosenbaum and Rubin 1983; Becker and Ichino 2002). PS's are calculated using a probit regression where the binary dependent variable takes a value of 1 for observations in the treated group and a value of 0 for non-treated observations. As independent variables $(X)$ those factors are included which have an impact on receiving the treatment and on the treatmentoutcome (Rubin and Thomas 1996; Heckman et al. 1997; Smith and Todd 2005). The estimated values of the dependent variable of this regression constitute the observations' PS's. Using the PS's the ATT can be calculated as:

$$
A T T(P(X))=E_{P(X) \mid D=1}\{E[Y(1) \mid D=1, P(X)]-E[Y(0) \mid D=0, P(X)]\},
$$

where $E_{P(X) \mid D=1}$ denotes the mean over the area of overlapping PS's for the treated and untreated group (Briggeman et al. 2009). The overlapping area of PS's is referred to as the area of 'common support' (Becker and Ichino 2002; Caliendo and Kopeining 2005). Thus, the ATT defined by (2) is the average difference in the treatment-outcome variable between the treated and the untreated group over the area of common support. While equation (2) is defined over the common support area some problems regarding the goodness of the matching can arise when solely relying on the common support criterion. First, intervals within the area of common support which are characterized by minor overlap between PS's of both groups are not considered (Caliendo and Kopeining 2005). Second, observations with PS's marginally outside 
the area of common support might still be adequate matches for observations of the opposing group slightly inside the area of common support (Smith and Todd 2005). In order to eliminate this 'common support problem' several matching algorithms can be applied in addition to the precondition of common support. We apply radius matching where only those untreated observations are included that lie within a specific radius (e.g. 0.05 or 0.1 ) of the PS's of observations in the treated group (Becker and Ichino 2002; Caliendo and Kopeining 2005). Radius matching accounts for areas with only minor PS overlap within the common support interval and considers suitable observations marginally outside this interval (Smith and Todd 2005).

Compared to this standard matching procedure our approach is slightly different. We do not attempt to match US and EU firms based on propensity scores that are calculated by means of all structural firm characteristics and afterwards calculate the ATT (i.e. differences in profits deviating from the norm between US and matched EU firms) based on (2). In contrast we take the treatment, which in the present case is either being an US or an EU firm, as exogenously given and solely match the firms based on the most important structural measure -firm size. Afterwards, for both the US and the matched EU panel we estimate the effect of several structural firm- and industry variables on the outcome variable, which in the present case is firm profit deviating from the norm. For this purpose we apply dynamic panel models based on the GMM estimator. The advantage of our approach is that it first provides comparable samples regarding the structural characteristic of interest -firm size- and afterwards allows to implement the GMM estimator which is the suitable econometric approach to capture the dynamics present in the data. The standard matching process described above, in turn, does not adequately consider the dynamic time series behavior of firm profits deviating from the norm.

\subsection{Dynamic panel model (GMM estimator)}

Following the matching process we estimate the persistence as well as the drivers of profits deviating from the norm for the US and the matched EU panel. Earlier studies analyzing the dynamics of firm profits over time (e.g. Mueller 1990; Gschwandtner 2005) employ a simple autoregressive process of order one (AR1) estimated with $\mathrm{OLS}^{2}$ :

$$
\pi_{i, t}=c+\lambda_{i} \pi_{i, t-1}+\eta_{i}+v_{i, t}
$$

\footnotetext{
${ }^{2}$ Some studies also implement a 'best lag model' which incorporates lags of higher order (e.g. Gschwandtner 2005).
} 
where $\eta_{i}$ is an unobserved firm-specific effect and $v_{i, t}$ is an observation specific error term (Baltagi 2008; Andres et al. 2009). In (3) $\pi_{i, t}$ is firm $i$ 's profitability deviating from the norm in period $t . \pi_{i, t}$ is defined as the difference between firm $i$ 's return on assets (ROA) in $t$ and the competitive norm which is proxied by average industry ROA in $t$ (e.g. Hirsch and Gschwandtner 2013). The estimated autoregressive coefficient $\hat{\lambda}_{i}$ can then be used for each firm as a measure of profit persistence as it indicates the percentage of profits deviating from the norm that sustains from period to period. Mean $\hat{\lambda}_{i}$ across firms in an industry can serve as an indicator for the competitive pressure within this sector as high competition decreases the likelihood that profits deviating from the norm persist. Some studies (e.g. Gschwandtner 2012) implement a second estimation step by regressing structural firm and industry variables such as firm size or industry concentration on $\hat{\lambda}_{i}$ in order to explain the latter.

However, the classical approach has the drawback that applying OLS to (3) leads to inconsistent and upward biased estimates of $\lambda_{i}$ due to an endogeneity bias caused by $\operatorname{Cov}\left(\pi_{i, t-1} ; \eta_{i}\right) \neq 0$. Similarly, the fixed effects (within) estimator leads to biased estimates. This estimator performs OLS on the equation with each variable adjusted by its mean over time. However, fixed effects estimates are still inconsistent and biased as $\operatorname{Cov}\left(\pi_{i, t-1} ; v_{i}\right) \neq 0$, where $v_{i}=v_{i t}-\bar{v}_{i}$ reflects the mean-adjusted error term (Baltagi 2008; Andres et al. 2009). Thus, to obtain consistent and unbiased estimates we apply the Arellano and Bond (1991) GMM estimator to an extended version of (3):

$$
\pi_{i, t}=c+\lambda \pi_{i, t-1}+\sum_{j} \alpha_{j}\left(Z_{j, i, t}\right)+\eta_{i}+v_{i, t}
$$

The autoregressive coefficient ( $\hat{\lambda}$ ) can then be used as a measure for the degree of profit persistence across the analyzed panel of firms. Additionally, a vector of $j$ time-variant structural firm and industry specific variables $(Z)$ is added to the model in order to estimate the impact of these variables on firm profits deviating from the norm over time. The GMM estimator firstdifferentiates the equation eliminating the time invariant firm-specific effect $\left(\eta_{i}\right)$. Afterwards, based on the assumption of no serial correlation in the error term $\left(v_{i t}\right)$ lags of the endogeneous independent variable $\left(\pi_{i, t-1}\right)$ can be used as valid instruments to estimate the first-differenced equation. Similar to Goddard et al. (2005) the independent variables included in $Z$ are treated 
as exogenous implying that they can instrument themselves (Andres et al. 2009; Roodman 2009, Hirsch and Gschwandtner 2013). However, Arellano and Bover (1995) and Blundell and Bond (1998) show based on Monte Carlo simulations that in cases where the autoregressive parameter $(\lambda)$ is large the difference GMM estimator behaves poorly as lagged values of the endogeneous independent variable $\left(\pi_{i, t-1}\right)$ constitute weak instruments. They extend the difference GMM estimator by focusing on a system of first-differenced and levels equations. Lagged differences of the endogeneous independent variable $\left(\pi_{i, t-1}\right)$ are then used as instruments for the levels equation in addition to the lagged values of the independent variable which are used as instruments for the first-differenced equation. This estimator is usually referred to as system-GMM (Baltagi 2008; Andres et al. 2009). ${ }^{3}$ We estimate equation (4) using the system-GMM estimator and additionally apply OLS as a robustness check and to quantify the bias of the classical approach.

\section{US and EU food processing industry population and sample}

In this section we first discuss structural characteristics of the US and EU food processing industry. We then present the construction, representativeness and descriptive statistics of our data and assess the comparability of the derived US and EU samples.

\subsection{US and EU food processing industry}

The first two columns of table 1 compare the US and EU-28 food processing industry based on key indicators. The EU-28 food industry is in general larger than the US food processing industry having both a higher value of overall sales and a much larger number of firms. The number of firms in the EU exceeds the respective US value by a factor of almost 10. In 2011 the US food processing industry contributes $14.7 \%, 14.2 \%$, and $10.3 \%$, to total manufacturing sales, employees and number of firms, respectively (USDoC 2014). The EU-28 food processing industry is characterized by a similarly high economic importance with shares of $14.8 \%$ of total manufacturing sales and $14.1 \%$ in manufacturing employees. However, the EU-28 food processing industries' share in the total number of manufacturing firms is with $13.8 \%$ higher than in the US (Eurostat 2014). Combined with the much larger number of food processors in

\footnotetext{
${ }^{3}$ Compared to the classical two-step AR(1) approach GMM has the disadvantage that we can only determine the impact of the independent variables $(Z)$ on profits deviating from the mean but not on the profit persistence measure $\hat{\lambda}$.
} 
the EU-28 this points towards significantly different size class structures between both industries.

This fact is also highlighted in the lower panel of table 1 which shows a significantly higher percentage of small firms in the EU-28 and a much higher percentage of larger firms in the US. While almost $80 \%$ of the firms in the EU-28 food sector have less than 10 employees, in the US only around $50 \%$ of the firms are that small. At the same time the percentage of firms with more than 20 employees is more than three times as large in the US than in the EU-28. Finally, the percentage of firms with more than 500 employees is 13.7 in the US, while in the EU-28 less than $1 \%$ of the firms have more than 250 employees. This significant disparity in the size class structure between the US and EU food processing industry can generally be explained by historical differences and the large cultural heterogeneity in Europe which hampers an upscaling of firms (Wijnands et al. 2007).

\section{Insert table 1 here}

\subsection{US and EU dataset}

The US sample was constructed using Standard and Poor's Compustat, a commercial database on financial information of US publicly quoted firms, and the US economic census (USDoC 2014). The EU sample is based on AMADEUS, a pan European balance sheet database including firms of all legal forms and size classes, and the Eurostat database (Eurostat 2014). While Compustat and AMADEUS provide firm-level data the US census and Eurostat serve for the construction of variables related to the subsectors of the food processing industry. Our analysis focuses on the time span 1996-2014.

When constructing the data panels it is important to consider the effect of possible survivorship biases on profitability that can occur due to bankruptcy or mergers and acquisitions (M\&As) (e.g. Gschwandtner 2005). Particularly the food industry is known for its high M\&A activity and several studies have shown that M\&As significantly influence not only the size and growth of firms (e.g. Connor and Geithman 1988) but also firm profitability (e.g. Bhuyan 2002). While historic merger waves occurred in the food sector during the 1980s (Connor and Geitham 1988) smaller waves also occurred during the period of analysis in the present study (Herger et al. 2008). Between 1997 and 2004 the US food industry was ranked number one globally regarding the number of food sector M\&As (Herger et al. 2008). Similarly, Kastrinaki and Stoneman (2011) show that between 1983 and 2007 the EU food industry has accounted for around 20\% of all EU merger activity. Moreover, Kastrinaki and Stoneman (2011) reveal common international patterns of food industry M\&A activity while Herger et al. (2008) point 
towards a high share of cross boarder acquisitions in the US and EU food industry. Although, our data does not contain the information necessary to quantify the effect of M\&As on profitability those findings indicate that both sectors were similarly affected by M\&A activity during the analyzed period.

Furthermore, it is important to consider possible effects of firm entry and exit. For example, Gschwandtner (2005) shows that surviving firms have in general higher profit persistence than firms that exit the market due to bankruptcy. We minimize the impact of possible survivorship bias due to bankruptcy as well as biases caused by a negligence of firm entry during the analyzed time span by employing the lowest feasible inclusion criterion regarding firm/year observations. Accordingly, we kept all firms with at least 6 years of available ROA data in the samples as this constitutes the minimum time series dimension necessary to adequately model the dynamics of profitability based on the GMM estimator (Baltagi 2008). Additionally, AMADEUS only reports $1.4 \%$ of exiting firms as bankrupt while the majority of firms exiting the database during the analyzed time span are either acquired or part of merger activity. Although for the US sample similar information is not available the majority of firms with less than 6 ROA observations shows missing values in the middle of the analyzed time frame implying that data incompleteness in those cases is not a sign for firm exit but rather of flaws in the database. The extent of survivorship bias due to bankruptcy in both samples should therefore not be significant.

In order to construct the US sample we first selected all 409 firms active in any of the 6-digit NAICS $^{4}$ codes between 311111 and 312140, i.e. firms that operate in food and beverage manufacturing. We deleted all firms with less than 6 years of available ROA data and removed outliers outside the interval of $+/-3$ standard deviations around the mean leading to a final sample of 104 firms. On average 8.3 years of data are available for each firm. Besides ROA, data on firm size, firm growth, market share as well as firms' financial risk is available to capture the impact of physical, human and organizational firm specific resources in accordance with the RBV. Finally, in line with the MBV concentration as well as size and growth of 6-digit food processing subsectors are added to the sample from the US census (USDoC 2014) to capture the impact of entry barriers and competition.

The EU sample was constructed similarly by including all firms active in any 4-digit NACE industry between DA1511 and DA1598 (i.e. the manufacturing of food and beverages) during 1996-2014 with at least 6 ROA observations. Due to data availability the EU sample is restricted to the 5 countries Belgium, France, Italy, Spain and the UK. However, with contributions of

\footnotetext{
${ }^{4}$ NAICS and NACE are the statistical classifications of economic activities in the US and the EU, respectively.
} 
$53.2 \%, 41.3 \%$ and $55.5 \%$ to total EU-28 food processing industry sales, employees and number of firms, respectively a significant share of the EU-28 food processing industry is covered by those 5 countries (cf. last column of table 1). Germany, the largest contributor to EU food processing industry turnover with $17.8 \%$ (Eurostat 2014) could not be included due to a lack of data as non-publicly quoted firms had no legal obligations to publicize accounting data until the year 2007 (Hirsch and Schiefer 2016). All observations outside +/- 3 standard deviations around the mean were dropped and industry data related to concentration as well as size and growth of 4-digit food processing subsectors from Eurostat's structural business statistics (Eurostat 2014) was added. As AMADEUS comprises firms of all legal forms (limited partnerships, private, publicly quoted, and cooperatives) and size classes the resulting sample comprises 3,541 firms and is significantly larger than the US sample. On average 13.8 years of data are available for each firm. ${ }^{5}$ We use this sample as a basis to construct a sample that matches the 104 publicly quoted US firms.

Table 2 presents descriptive statistics of firm and industry characteristics in the US and the EU samples. We first describe the variables for the US sample and the initial EU sample. The results for the matched EU sample in the third column will be discussed below subsequent to the matching procedure. As variable definitions are not necessarily identical between the two databases we selected all variables under careful consideration of comparability based on the definitions of individual balance sheet items from the database providers. ${ }^{6}$

ROA is calculated as the quotient of firms' profit/loss before taxation, plus interest ${ }^{7}$, and total assets. There has been a vast debate regarding the suitability of accounting profit measures such as ROA as those measures can suffer from biases due to profit smoothing or cross subsidization (e.g. Fisher and McGowan 1983; Long and Ravenscraft 1984). Some studies therefore use alternatives such as economic value added (EVA) developed by Stern Steward and Co., which measures the economic returns generated for shareholders or Tobins $q$. However, Biddle et al. (1997) illustrate that EVA is outperformed by balance sheet earnings as a performance proxy as returns and firm values are more strongly correlated with earnings than with EVA. Therefore, to assure comparability to previous literature we use ROA as the proxy for firm profitability. Moreover, correlation coefficients between ROA and the value added measure provided by AMADEUS exceed 0.8 and are significant at $\mathrm{p}<0.01$ for each year and

\footnotetext{
${ }^{5}$ An earlier version of this EU sample covering the years 1996-2008 has been analyzed regarding profit persistence by Hirsch and Gschwandtner (2013).

${ }^{6}$ Detailed definitions of all variables from the database providers can be found in Table A1 in the appendix.

${ }^{7}$ To make ROA independent of the source of funds used, interest has to be included in the numerator.
} 
country $^{8}$. According to table 2 ROA is on average significantly lower in the US sample than in the EU sample pointing towards higher competition in the US, maybe due to the lower concentration in the retail sector and less potential subsidies than in the EU.

The average firm size, measured by firms' total assets, is with $\$ 3.3 \mathrm{bn}$. significantly higher in the US sample than in the EU sample where the respective value is only $\$ 25.9 \mathrm{~m}$. Although this divergence confirms the results for the population in table 1, small firms are significantly underrepresented in the US sample caused by the fact that Compustat only provides data for publicly quoted firms which are usually larger. As can be seen from the size class distribution at the bottom of the table, similar to the population, we have mainly large firms in the US sample (84.0\%) and mainly small and micro firms in the EU sample (87.8\%). However, the yearly growth factor of firms` total assets, is on average higher in the EU than in the US.

Market share was calculated for each firm as the ratio of its sales to the overall sales in the NAICS/NACE sector in which the firm operates. Surprisingly, average market share of firms in the US sample is with $3.2 \%$ only slightly larger than in the EU sample where the average firm has a market share of $2.2 \%$. However, as will become apparent below in comparison to the EU sample the US sample is characterized by a larger share of firms that operate in subsectors that generate higher outputs and vice versa. Hence, despite the much larger average firm size market shares in the US sample do not significantly exceed market shares in the EU sample.

Firms in the US sample engage on average significantly less in short-term and long-term financial risk than firms in the EU. Average short-term risk, measured by the reciprocal of a firm's current ratio, i.e. the quotient of current liabilities to current assets, is almost twice as large in the EU. Similarly, long-term risk measured by the firms gearing ratio, i.e. the quotient of non-current liabilities to shareholder funds is lower in the US (1.3) than it is in the EU sample (1.4).

We now turn our attention to industry related variables. As suggested by Cotterill (1986) concentration is measured by the Herfindahl-Hirschman Index (HHI) ${ }^{9}$. The HHI is calculated as the sum of the squared market shares of firms ${ }^{10}$ in each 4-digit NACE and 6-digit NAICS subsector. Mean HHI values are below the 0.15 threshold of moderately concentrated markets in both the US and EU sample indicating that the majority of firms operate in industries that are characterized by low concentration (USDoJ 2010).

\footnotetext{
${ }^{8}$ This only holds for the EU-5 countries as VA is not available for the US.

${ }^{9}$ Cotterill (1986) shows that the HHI outperforms the four-firm concentration ratio as a concentration measure.

${ }^{10}$ For industries with less than 50 firms the total number of firms is used for the calculation.
} 
Industry size and yearly growth factors are measured by the sales of each 6-digit NAICS and 4-digit NACE food processing subsector, respectively. Despite the lower number of total food processing sales in the population average industry size is significantly larger in the US sample ( $\$ 20.3$ billion vs. $\$ 6.6$ billion). This is due to the fact that in the EU sample a larger fraction of firms is active in subsectors that generate lower outputs (e.g. NACE DA1593 'Manufacture of wines' or DA1561 'Manufacture of grain mill products'). Nevertheless, firms in the EU sample operate in industries that grow stronger as the average yearly growth factor of industry sales is with 1.03 significantly larger than in the US sample where growth stagnates.

\section{Insert table 2 here}

When comparing the EU and US food industry another important question refers to the ownership of the firms and its impact on profitability. It is well known that almost $45 \%$ of the US food economy has an ownership structure that is regarded as closely held and that this type of ownership can significantly influence firm profitability (Boland et al. 2008). For example, Anderson and Reeb (2003) and Boland et al. (2008) show that the percentage of firms in the US food industry with a significant share of family-ownership is particularly high. Similarly, in the EU food economy in most industries a significant number of family owned firms can be found (Wijnands et al. 2007, Palpacuer and Tozanli 2008). For example, Mandl (2008) shows that the share of family businesses in the EU food sector is $27 \% .{ }^{11}$ Nevertheless, while AMADEUS provides a unique coverage of the EU food industry`s population of firms it is questionable whether closely held firms are sufficiently covered by the Compustat database. Therefore, to assess the degree of family ownership in the US sample we used information about insider/individual ownership available in S\&P Capital $\mathrm{IQ}^{12}$ which can be assumed to be highly correlated with family ownership. $32.9 \%$ of the companies in our sample had an insider/individual ownership of $10 \%$ or more. The percentage of firms with $30 \%$ or more insider/individual ownership and at least one insider on the board is 18.4 and the percentage of firms with $50 \%$ or more insider/individual ownership and at least one insider on the board is 9.5. If we compare the average ROA for these firms with the average ROA of the firms with less than 50\% insider/individual ownership we find that companies with a higher percentage of insider/individual ownership perform on average better and that the difference between the means is statistically significant at the $5 \%$ level. This seems to confirm the results of Anderson and Reeb (2003) and Boland et al. (2008) where it is found that family ownership is both

\footnotetext{
${ }^{11}$ Prominent examples of family-owned food sector firms are Campbell and Mars for the US and the Italian pasta producer Barilla for the EU (Boland et al. 2008, Palpacuer and Tozanli 2008).

${ }^{12}$ Available at www.capitaliq.com
} 
prevalent and that a 'greater percentage of equity held by insiders such as management and family members leads to greater performance'. We therefore infer that our samples adequately reflect the presence of family- ownership and the respective impact on profitability.

\section{Estimation results}

\subsection{Propensity score matching results}

Propensity scores are estimated using a probit model where the binary dependent variable takes a value of 1 for observations in the US sample and a value of 0 for observations in the EU sample. As independent variable we use firm size as the structural characteristic of interest. In order to avoid sample selection bias, for the matching process we use firm sales instead of total assets, our prime firm size measure. This is necessary as we aim to afterwards include total assets as an independent variable to explain profits deviating from the norm. The probitregression results indicate that firm size measured by sales has a significantly positive impact on the probability that a firm is in the US sample.

The third column of table 2 shows the firm size distributions after the matching process. From the initial EU sample 1,395 firms are identified, based on the area of common support and the radius matching algorithm, to match the 104 US firms. ${ }^{13}$ The fraction of micro firms is significantly reduced in the EU sample from $64.5 \%$ to $22.4 \%$. However, the fraction of large firms remains significantly smaller in the EU sample than in the US sample.

The balancing property serves as a goodness measure for the matching process. In the present case it is fulfilled at $\mathrm{p}<0.01$ which indicates that the size of firms in the US and the matched EU sample is similar even within PS subsets (i.e. quantiles) over the common support area (Cavatassi et al. 2011). Additionally, the reduction in the standardized bias ${ }^{14}$ can be used as a measure for the success of the matching. Previous studies interpret a reduction of this bias by around 3\% as sufficient (Caliendo and Kopeining 2005). Nevertheless, the matching process only leads to a reduction of the bias by $1.1 \%$ indicating that significant differences in size classes remain. Those also become evident from table 2 which indicates that although average firm size in the EU sample increases from $\$ 25.9 \mathrm{~m}$. to $\$ 61.0 \mathrm{~m}$. in total assets this value remains significantly smaller than the US value of $\$ 3.3 \mathrm{bn}$. Nonetheless, the matched EU sample likely

\footnotetext{
${ }^{13}$ Several estimation attempts with different radii $(0.15,0.1$ and 0.05$)$ led to identical results.

${ }^{14}$ The standardized bias is calculated as: $S B=\left(\bar{x}_{1}-\bar{x}_{0}\right) / \sqrt{0.5 *\left(V\left(x_{1}\right)+V\left(x_{0}\right)\right)}$, where $\bar{x}_{1}, V\left(x_{1}\right)$ and $\bar{x}_{0}, V\left(x_{0}\right)$ are mean and variance of firm size in the US and the matched EU sample, respectively.
} 
represents a similar part of the size class distribution of the EU food processing industry as the one represented by the 104 US firms. We suppose that this approach is more meaningful than simply focusing on EU firms that have exactly the same size as the US firms as firms would be less comparable regarding their competitive situation. ${ }^{15}$

\subsection{Explaining profits deviating from the norm}

The results of the GMM dynamic panel estimation are presented in table 3 in the first two columns. For each variable we also calculated the statistical difference between the US and EU5 coefficient.

Results indicate that the short-run persistence parameter $(\hat{\lambda})$ is positive and significant in both samples, meaning that past year`s profits have a significant impact on this year`s profits and therefore profit persistence exists. Moreover, there is no significant difference between the US and EU persistence coefficient at the 5\%-level which confirms that the matching process has generated US and EU firms that operate in comparable competitive situations in their respective industries. The $\hat{\lambda}$ values of 0.293 for the US and 0.340 for the EU are lower compared to other manufacturing sectors indicating higher competitive pressure in the food processing industry. ${ }^{16}$ For example, Gschwandtner (2012) using GMM with a similar set of explanatory variables finds $\hat{\lambda}$ values between 0.549 and 0.722 for the entire US manufacturing sector while Goddard et al. (2005) find $\hat{\lambda}$ values between 0.323 and 0.452 for entire manufacturing sectors of the same five EU countries.

We now focus on firm-specific characteristics that in accordance with the RBV should affect profitability. The impact of firm size on profitability deviating from the norm is positive and significant in both samples. Moreover, the coefficients are not significantly different. Hence economies of scale seem to play an important role in the US and EU food processing industry. Moreover, larger size allows to better deal with pre-market approval procedures, advertising costs, to establish reputation and to counteract the market power of large retailers (Wijnands et al. 2007). Firm growth in turn has no significant impact on profits deviating from the norm.

Similarly, market share is insignificant both in the EU and in the US. Usually a higher market share is expected to have a positive impact on profits deviating from the norm. However, firms

\footnotetext{
${ }^{15}$ An alternative matching strategy would have been to first ensure homogeneity across EU firms by performing PSM for all 10 combinations between the 5 EU countries. However, this was neglected as similar to Hirsch and Gschwandtner (2013) we want to consider the EU food processing industry in its entirety as a single market of goods and services.

${ }^{16}$ Following Goddard et al. (2005) for the EU estimation an (insignificant) 3rd order lag of the dependent variable had to be retained to handle problems of second order autocorrelation in the residuals.
} 
with high market shares may also have transparency problems and diseconomies of scope that counteract the positive influence leading to an insignificant effect in the end. Moreover, Prescott et al. (1986) show that the impact of market share is influenced by the external environment in which firms operate and can therefore also be negative.

Short-term financial risk negatively impacts in both samples and the coefficients are not significantly different. A negative impact has also been found by Hirsch and Gschwandtner (2013) for the EU. Short-term risk may put high pressure on the financial stress of firms and is expected to have a negative impact. Long-term financial risk (gearing) however, may help the firm to invest in R\&D and recover from eventual financial distress. Thus, it may enable firms to make investments that help the company to grow and to reach a specific established market position or a critical firm size that ensures its competitiveness. Furthermore, Chaddad and Mondelli (2013) mention that financial pressure of debt reduces free cash flow, and may lead managers to invest more wisely and not to waste firm resources in perquisites and unprofitable growth. Accordingly, a positive and significant impact of long-term debt is detected for the US. However, the impact of long-term debt is insignificant in the EU and the coefficient is significantly smaller compared to the US. Goddard et al. (2005) who find a negative impact of gearing for EU manufacturing firms conclude that 'highly leveraged firms may suffer in increasingly competitive markets, as they need to use a higher proportion of gross profits to service debt'. For the EU it is hence likely the case that the positive and negative effects of long term debt neutralize each other leading to the insignificant impact.

The focus shall now be on those structural industry factors which according to the MBV determine the degree of entry barriers and competition. The results show that the impact of industry concentration is positive in both samples although only significant in the EU. Moreover, the respective coefficient is significantly higher in the EU. For the EU it therefore appears to be the case that high concentration prevents entry, leading to less competition and higher profits deviating from the norm. Nevertheless, strong concentration can also lead to intense rivalry between the few large firms resulting in a negative impact. Hence for the US it is likely the case that both effects cancel each other out leading to the insignificant impact of concentration.

Industry size does not impact significantly on profits deviating from the norm and there is no significant difference between the two samples. However, there is a significant difference between the US and EU in the impact of industry growth on profitability deviating from the norm. While the impact is positive and significant in the EU, it is significantly negative in the US. This indicates that US firms likely engage in stronger non-profit competition such as 
advertising when the industry grows which in turn reduces profitability deviating from the norm. In contrast firms in growing EU industries appear to behave more cooperatively which increases their profitability on average.

Regarding goodness of fit parameters the Wald statistics indicate the overall significance of both models at the $1 \%$ level. Lags of second or higher order have been used as instruments for the endogeneous independent variable in both models and the Hansen test does not reject the null hypothesis that this is the correct implementation of instruments. Moreover, for none of the models the null hypothesis of no second-order autocorrelation is rejected indicating the consistency of the GMM estimator (Arellano and Bond 1991). Finally, the OLS results in columns 3 and 4 are used as robustness checks. If the GMM results are correct then the autoregressive coefficient shall be below the OLS results and we can observe that this is the case for both samples. Moreover, the OLS coefficients on explanatory firm- and industry characteristics reflect those generated by the GMM estimator indicating robustness of the results.

\section{Insert table 3 here}

Columns 5 and 6 of table 3 present specifications to assess the effect of the economic crisis where observations falling in the time span of the crisis (2008-2009) are excluded ${ }^{17}$. The effect is reflected by an increase in the short-run persistence measure $(\hat{\lambda})$ in the US and EU to 0.360 and 0.372 , respectively. However, this increase is not statistically significant confirming that the food industry is a rather crisis proof sector (Lienhardt 2004). The impact of the remaining explanatory variables remains constant with the exception of long-term debt in the US where the respective coefficient remains positive but becomes insignificant. Moreover, the difference to the respective EU coefficient becomes insignificant. This may suggest that during macroeconomic crises debt can enable US firms to make investments that lead to growth and a specific critical firm size and market position that ensures competitiveness.

\section{Conclusions}

The food processing industries in the US and in the EU differ strongly with respect to the size of firms with US food processors being on average significantly larger than firms in the EU food processing industry. When it comes to empirical analyses of US and EU food processors' profitability the divergence regarding size is amplified by low data availability for smaller US

\footnotetext{
${ }^{17}$ We have moreover estimated specifications where the time frame of the economic crisis was captured through dummy variables. However, the respective coefficients showed no significant impact and the impact of all other coefficients remained unchanged. These results are available upon request.
} 
food processors. Therefore, PSM has been used to derive samples of comparable firm size. In addition to assess how well integrated US and EU food processors have been during the analyzed period we discuss the impact of industry specific events such as M\&A waves, the economic crisis as well as ownership structure on profitability in both regions.

Subsequently, we have analyzed the drivers of profit persistence in the US food processing sector and provide a comparison to the results of the matched EU sample. To our knowledge, such an analysis -in particular for the US- has not been carried out before.

We find that profit persistence of food processing firms is lower compared to other manufacturing sectors both in the US and the EU indicating a high degree of competitive pressure. Moreover, the results show that the food industry is a rather crisis proof sector as food processors` profit persistence was only marginally affected by the economic crisis.

The main drivers of profitability deviating from the norm turn out to be firms' size and financial risk. In both regions larger firms achieve a higher level of profits deviating from the norm, a result that has also been previously obtained for the EU (Hirsch and Gschwandtner 2013). Thus, large firms may be able to perform more advertising, have higher consumer reputation and are better able to cope with competition pressures. While short-term financial risk in turn affects profitability negatively in both regions due to increased financial stress of firms a significant difference between the US and the EU can be detected regarding the impact of long-term financial risk. While long-term risk has no significant impact on profit deviating from the norm in the EU it impacts positively on firms in the US when observations that fall into the period of the economic crisis and its aftermaths are included. As discussed before, longterm debt can enable firms to make the necessary investments that help to ensure competitiveness in times of crisis. Finally, firms in the US and the EU differ with respect to the impact of concentration and industry growth on profit deviating from the norm. For food industry subsectors in the EU high concentration seems to prevent entry, leading to less competition and higher profits deviating from the norm while negative effects of concentration on profitability due to e.g. intense rivalry between the few large firms cannot be detected. Regarding industry growth, in the EU the fact that the industry as a whole grows may impact positively on the perception of consumers and may increase firms' profit. Contrarily, in the US industry growth may lead to more ferocious competition processes which in turn impacts negatively on firms' profit deviating from the norm.

Some shortcomings of this article are the omission of important intangible firm-specific resources such as R\&D activity, patents, and reputation due to data unavailability. Second, although we infer that M\&A activity during the analyzed time period has affected both food 
sectors to a similar degree the present data does not allow for an investigation of its effect on profits deviating from the norm. Moreover our data only allows to quantify the impact of family/insider ownership for the US industry while respective data is not available for the EU. Third, compared to NEIO approaches which allow a detailed modeling of specific subindustries the present analysis can only provide overarching insights on the structural drivers of profitability across industries of the food sector. However, the food industry is affected by a large number of food contamination incidents and food scandals that occur locally or affect specific food industry subsectors and which seem to appear with equal regularity in both regions. ${ }^{18}$ While the relevance of such incidents cannot be assessed by our holistic approach NEIO would allow for a more detailed modelling of the effects on firm profitability in the affected subsectors.

The results have not only purely descriptive value but can also be useful when designing management implications and policies aimed at supporting food sector firms or the food sector as a whole. This is important as today firms are facing economic circumstances characterized by reduced entry barriers and possibilities to operate in previously hardly accessible foreign markets. Those developments are a consequence of intensified globalization represented by trade agreements such as the NAFTA or the formation of a single market for goods and services within the EU. However, these deregulations of borders and international trade have led to a significant intensification of competition among firms across many sectors. The comparably low short-run persistence values $(\hat{\lambda})$ which have been estimated for the US and EU food industry also reflected this development.

Moreover, pressure on the margins and competitiveness of food processors is intensified by increasing uncertainty in raw material markets and strong concentration in retail sectors. (Schiefer 2011). While five-firm concentration ratios already exceed $70 \%$ in many EU member countries concentration is slightly weaker in the US retail sector, but shows an increasing trend (Wijnands et al. 2007; Wood 2013). A high and constantly growing share of private labels further increases competitive pressure on food processors (European Commission 2011). In the EU the food retail sector has already drawn attention of competition authorities with a focus of retailer's buyer power vis-à-vis the producers (European Competition Network, 2012, Davis and Reilly 2010, Dobson et al. 2003). The detected low degree of profit persistence in the food processing industry points towards the need for policy interventions at the retail level.

\footnotetext{
${ }^{18}$ Examples are the UK horsemeat scandal in 2013, the Belgian Dioxin scandal in 1999, the 2011 E. coli outbreak which affected several EU countries or the 2010 US salmonella outbreak which led to a recall of more than 500 million eggs.
} 
Moreover, the positive impact of firm size on profitability indicates that small firms are in a disadvantageous position. Thus, policy measures which address the food processing industry could focus on a decrease of administrative burdens particularly for the large number of small enterprises. Furthermore, measures that decrease unfavorable financial risk factors -particularly short term risk- might strengthen food processors and help to improve their competitiveness. Finally, the US results indicate that in times of economic crisis measures that facilitate access to long-term debt can counter the negative impact of the crisis.

\section{References}

Anderson, R.C. and Reeb, D.M. 2003. Founding-family ownership and firm performance: evidence from the S\&P 500. The Journal of Finance 58(3): 1301-1328

Andres, C., Betzer, A., Goergen, M. and Renneboog, L. 2009. Dividend policy of German firms. A panel data analysis of partial adjustment models. Journal of Empirical Finance, 16: 175-187.

Arellano, M. and Bond, S. 1991. Some tests of specification for panel data: Monte Carlo evidence and an application to employment equations. Review of Economic Studies 58(2): 277-297.

Arellano, M. and Bover, O. 1995. Another look at the instrumental variable estimation of errorcomponents models. Journal of Econometrics, 68: 29-51.

Austin, P.C. 2008. A critical appraisal of propensity-score matching in the medical literature between 1996-2003. Statistics in Medicine 27: 2037-2049.

Bain, J. S. 1956. Barriers to New Competition. Cambridge, UK: Harvard University Press.

Bain, J. S. 1968. Industrial Organization. New York: John Wiley \& Sons.

Baltagi, B.H. 2008. Econometric Analysis of Panel Data. Chichester, UK: Wiley.

Barney, J. B. 1991. Firm resources and sustained competitive advantage. Journal of Management 17(1): 99-120.

Becker, S.O. and Ichino, A. 2002. Estimation of average treatment effects based on propensity scores. The Stata Journal 2(4): 258-377.

Bhuyan, S. 2002. Impact of Vertical Mergers on Industry Profitability: An Empirical Evaluation. Review of Industrial Organization 20: 61-79

Blundell, R. and Bond, S. 1998. Initial conditions and moment restrictions in dynamic panel data models. Journal of Econometrics, 87: 115-143. 
Boland, M.A., Golden, B.B. and Tsoodle, L.J. 2008. Agency Theory Issues in the Food Processing Industry. Journal of Agricultural and Applied Economics 40(2): 623-634.

Bontemps, C., Bouamra-Mechemache, Z., and Simioni, M. 2013. Quality labels and firm survival: some first empirical evidence. European Review of Agricultural Economics 40(3): 413-439.

Bou, J.C. and Satorra, A. 2007. The persistence of abnormal returns at industry and firm levels: Evidence from Spain. Strategic Management Journal 28(7): 707-722.

Bresnahan, T.F. (1981). Departures from marginal-cost pricing in the american automobile industry. Journal of Econometrics 17: 201-227.

Briggeman, B.C., Towe, C.A., and Morehart, M.J. 2009. Credit Constraints: Their Existence, Determinants, and Implications for U.S. Farm and Nonfarm Sole Proprietorships. American Journal of Agricultural Economics 91(1): 275-289.

Caliendo, M. and Kopeining, S. 2005. Some Practical Guidance for the Implementation of Propensity Score Matching. IZA Discussion Paper No. 1588. IZA Discussion Paper Series.

Carlton, D.W. and Perloff, J. M. 2005. Modern Industrial Organization. Boston, Mass.: Pearson Addison-Wesley.

Cavatassi, R., Salazar, L., González-Flores, M., and Winters, P. 2011. How do Agricultural Programmes Alter Crop Production? Evidence from Ecuador. Journal of Agricultural Economics, 62(2): 403-428.

Chacar, A. and Vissa, B. 2005. Are emerging economies less efficient? Performance persistence and the impact of business group affiliation. Strategic Management Journal 26(10): 933946.

Chaddad, F.R, and Mondelli, M.P. 2013. Sources of Firm Performance Differences in the US Food Economy. Journal of Agricultural Economics, 64(2), 382-404.

Claver, E., Molina, J. and Tarí, J. 2002. Firm and Industry Effects on Firm Profitability : A Spanish Empirical Analysis. European Management 20(3): 321-328.

Connor, J.M. and Geithman, F.E. 1988. Mergers in the Food Industries: Trends, Motives, and Policies. Agribusiness 4(4): 331-346.

Cotterill, R.W. 1986. Market Power in the Retail Food Industry: Evidence from Vermont. The Review of Economics and Statistics 68(3): 379-386.

Cubbin, J. and Geroski, P.A. 1990. The persistence of profits in the United Kingdom. In Mueller, D. C. (ed.), The dynamics of company profits. Cambridge, UK: Cambridge University Press, 147-167. 
Davis, A. and Reilly, A. 2010. Market power, market outcomes, and remedies in the UK groceries market. Agricultural Economics 41: 93-108.

Dehejia, R.H., and Wahba, S. 1999. Causal Effects in Nonexperimental Studies: Reevaluating the Evaluation of Training Programs. Journal of the American Statistical Association, 94(448), 1053-1062.

Dobson, W. P, M. Waterson and S. Davies. 2003. The Patterns and Implications of Increasing Concentration in European Food Retailing. Journal of Agricultural Economics 54(1): 111125.

Dorsey, S. and Boland, M. 2009. The impact of integration strategies on food business firm value. Journal of Agricultural and Applied Economics 41(3): 585-598.

European Commission 2005. The new SME definition. Enterprise and Industry Publications, Luxembourg: European Commission.

European Commission 2011. The impact of private labels on the competitiveness of the European food supply chain. Enterprise and Industry Magazine. Luxembourg: European Commission.

Eurostat 2014. Annual detailed enterprise statistics on manufacturing subsections DA-DE and total manufacturing. Luxembourg: European Commission.

Fisher, F.M. and McGowan, J.J. 1983. On the Misuse of Accounting Rates of Return to Infer Monopoly Profits. American Economic Review 73(1): 82-97.

Gallizo, J.L., Gargallo, P., Saladrigues, R. and Salvador, M. 2014. The persistence of abnormal return on assets: an exploratory analysis of the performance of firms by country and sector. Applied Stochastic Models in Business and Industry. DOI: 10.1002/asmb.2034.

Glen, J., Lee, K. and Singh, A. 2001. Persistence of profitability and competition in emerging markets. Economic Letters 72(2): 247-253.

Goddard, J.A., Tavakoli, M. and Wilson, J. O. S. 2005. Determinants of profitability in European manufacturing and services: evidence from a dynamic panel model. Applied Financial Economics 15(18): 1269-1282.

Goddard, J.A. and Wilson, J.O.S. 1999. The persistence of profit: a new empirical interpretation. International Journal of Industrial Organization 17(5): 663-687.

Gschwandtner, A. 2005. Profit persistence in the 'very' long run: evidence from survivors and exiters. Applied Economics 37(7): 793-806.

Gschwandtner, A. 2012. Evolution of Profit Persistence in the US: Evidence from three periods, The Manchester School, 80(2), 172-209. 
Heckman, J.J., Ichimura, H., and Todd, P.E. 1997. Matching as an Econometric Evaluation Estimator: Evidence from Evaluating a Job Training Programme. Review of Economic Studies, 64: 605-654.

Heinrich, C., Maffioli, A., and Vázques, G. 2010. A Primer for Applying Propensity-Score Matching. Impact-Evaluation Guidelines, Technical Notes No. IDB-TN-161. Office of Strategic Planning and Development Effectiveness, Inter-American Development Bank.

Herger, N., Kotsogiannis, C. and McCorriston, S. 2008. Cross-border acquisitions in the global food sector. European Review of Agricultural Economics 35(4): 563-587.

Hirsch, S. 2014. Abnormal profits and profit persistence: evidence from the European food industry. Dissertation University of Bonn.

Hirsch, S. and Gschwandtner, A. 2013. Profit persistence in the food industry: evidence from five European countries. European Review of Agricultural Economics, 40(5): 741-759.

Hirsch, S., Schiefer, J., Gschwandtner, A. and Hartmann, M. 2014. The Determinants of Firm Profitability Differences in EU Food Processing. Journal of Agricultural Economics, 65(3): 703-721.

Hirsch, S., and Schiefer, J. (2016) What Causes Firm Profitability Variation in the EU Food Industry? A Redux of Classical Approaches of Variance Decomposition. Agribusiness: an International Journal, 32(1): 79-92.

Hsiao, C. 2007. Analysis of Panel Data, $2^{\text {nd }}$ ed. Cambridge University Press: New York.

Huang, Z., Lou, Y., and Taitel, M. 2013. A case Application of Propensity Score Matching in the Outcomes Evaluation of Medication Therapy Management at Retail Pharmacy. SAS Global Forum 2013, Paper 215-2013.

Kadiyali, V., Sudhir, K., Vithala, R.R. (2001) Structural analysis of competitive behavior: New Empirical Industrial Organization methods in marketing. International Journal of Research in Marketing 18: 161-186.

Kastrinaki, Z. and Stoneman, P. 2011. Merger Patterns in the European Food Supply Chain. International Journal of the Economics of Business 18(3): 463- 487

Key, N. and McBride, W.D. 2014. Sub-therapeutic Antibiotics and the Efficiency of U.S. Hog Farms. American Journal of Agricultural Economics 96(3): 831-850.

Lienhardt, J. 2004. The food industry in Europe. Statistics in focus 39/2004. Luxembourg: European Communities.

Long, W.F, and Ravenscraft, D.J. 1984. The Misuse of Accounting Rates of Return: Comment. The American Economic Review 74(3): 494-500. 
Mandl, I. 2008. Overview of Family Business Relevant Issues. Vienna: Austrian Institute for SME Research.

McGahan, A.M. and Porter, M.E. 2003. The emergence and sustainability of abnormal profits. Strategic Organization 1(1): 79-108.

Mueller, D.C. 1986. Profits in the Long Run. Cambridge, UK: Cambridge University Press.

Mueller, D.C. 1990. Dynamics of Company Profits: An International Comparison. Cambridge, UK: Cambridge University Press.

Palpacuer, F. and Tozanli, S. 2008. Changing governance patterns in European food chains: the rise of a new divide between global players and regional producers. Transnational Corporations 17(1): 69-98.

Pattitoni, P., Petracci, B. and Spisni, M. 2014. Determinants of profitability in the EU-15 area. Applied Financial Economics. DOI: 10.1080/09603107.2014.904488.

Penrose, E.T. (1959). The theory of the growth of the firm. New York: John Wiley and Sons.

Perkins, S.M., Tu, W., Underhill, M.G., Zhou, X. and Murray, M.D. 2000. The Use of Propensity Scores in Pharmacoepidemiologic Research. Pharmacoepidemiology and Drug Safety, 9: 93-101.

Peteraf, M.A. 1993. The cornerstones of competitive advantage: A resource based view. Strategic Management Journal 14(3): 179-191.

Porter, M.E. 1980. Competitive Strategy. Techniques for Analyzing Industries and Competitors. New York: Free Press.

Prescott, J.E., Kohli, A.K. and Venkatraman, N. 1986. The market share-profitability relationship:an empirical assessment of major assertions and contradictions. Strategic Management Journal 7(4): 377-394.

Rubin, D.B., and Thomas, N. 1996. Matching Using Estimated Propensity Scores: Relating Theory to Practice. Biometrics, 52(1): 249-264.

Roodman, D. 2009. How to do xtabond2: An introduction to difference and system GMM in Stata. The Stata Journal 9(1): 86-136.

Rosenbaum, P.R., and Rubin, D.B. 1983. The Central Role of the Propensity Score in Observational Studies for Causal Effects. Biometrika, 70(1): 41-55.

Schiefer, J. 2011. Was bestimmt die Rentabilität in der Lebensmittelindustrie? Eine empirische Analyse unternehmensinterner und-externer Effekte. Hamburg: Dr. Kovac.

Schumacher, S.K. and Boland, M.A. 2005. The persistence of profitability among firms in the food economy. American Journal of Agricultural Economics 87(1): 103-105. 
Smith, J.A., and Todd, P.E. 2005. Does matching overcome LaLonde's critique of nonexperimental estimators? Journal of Econometrics, 125(1-2): 305-353.

Tirole, J. 1988. The Theory of Industrial Organization. Cambridge: MIT Press.

USDoC 2014. Annual Survey of Manufactures. Economic Census United States Census Bureau. U.S. Department of Commerce.

USDoJ 2010. Horizontal Merger Guidelines 2010. Washington: U.S. Department of Justice and the Federal Trade Commission.

Waring, G.F. 1996. Industry Differences in the Persistence of Firm-Specific Returns. The American Economic Review 86(5): 1253-1265.

Weiss, C.R. and Wittkopp, A. 2005. Retailer concentration and product innovation in food manufacturing. European Review of Agricultural Economics 32(2): 219-244.

Welge, M. K. and Al-Laham, A. (2008) Strategisches Management. Wiesbaden, Germany: Gabler.

Wiggins, R.R. and Ruefli, T.W. 2002. Sustained Competitive Advantage. Organization Science 13(1): 82-105.

Wijnands, J.H.M., Meulen, B.M.J. van der and Poppe, K.J. 2007. Competitiveness of the European Food Industry: An economic and legal assessment 2007. Luxembourg: European Commission.

Wood, S. 2013. Revisiting the US food retail consolidation wave: regulation, market power and spatial outcomes. Journal of Economic Geography 13(2): 299-326.

Yurtoglu, B.B. 2004. Persistence of firm-level profitability in Turkey. Applied Economics 36(6): 615-625. 


\section{Tables}

Table 1. Key indicators US and EU food processing industry (2011)

\begin{tabular}{|c|c|c|c|c|c|}
\hline & US & & EU-28 & & $\begin{array}{l}\mathrm{J}-5 \text { (Be, Fr, } \\
\text {, Sp, UK) }\end{array}$ \\
\hline Sales (bn. \$) $)^{a}$ & 808.233 & & $1,344.441$ & & 715.656 \\
\hline No. of firms & 30,384 & & 289,199 & & 160,504 \\
\hline Employees (m.) & 1.559 & & 4.284 & & 1.770 \\
\hline \multicolumn{6}{|l|}{ Size class distribution (\%) } \\
\hline 0-9 employees & 50.62 & & 78.68 & & 85.74 \\
\hline $10-19$ & 13.11 & & 10.86 & & 7.07 \\
\hline$>20$ & 36.27 & & 10.46 & & 7.19 \\
\hline \multicolumn{6}{|l|}{$\begin{array}{l}\text { Available size classes } \\
\text { for }>20 \text { employees }{ }^{b}\end{array}$} \\
\hline 20-99 & 15.45 & $20-50$ & 5.79 & $20-50$ & 4.34 \\
\hline $100-500$ & 7.14 & $50-250$ & 3.80 & $50-250$ & 2.28 \\
\hline$>500$ & 13.70 & $>250$ & 0.86 & $>250$ & 0.57 \\
\hline \multicolumn{6}{|c|}{$\begin{array}{l}\text { Data sources: Eurostat (2014) and USDoC (2014) } \\
\text { Notes: food processing industry in the EU-28 defined as NACE Rev. } 1.1 \text { division } 15 \text { i.e. 'Manufacture of food } \\
\text { products and beverages'. US food processing industry defined by NAICS codes } 311 \text { 'Food manufacturing' and } \\
3121 \text { 'Beverage manufacturing' } \\
\text { a Value of shipments for the US } \\
\text { b Data based on identical size classes for the EU and US food processing industries is not available for firms } \\
\text { with > } 20 \text { employees. }\end{array}$} \\
\hline
\end{tabular}


Table 2. Descriptive statistics of firm and industry characteristics

US

EU-5

\begin{tabular}{|c|c|c|c|c|c|c|}
\hline & \multicolumn{2}{|c|}{ (no. of firms = 104; ) } & \multicolumn{2}{|c|}{$\begin{array}{c}\text { Initial sample } \\
\text { (no. of firms=3,541; ) }\end{array}$} & \multicolumn{2}{|c|}{$\begin{array}{c}\text { Matched sample } \\
\text { (no of firms=1,395; ) }\end{array}$} \\
\hline Variable & Mean & Stdv. & Mean & Stdv. & Mean & Stdv. \\
\hline \multicolumn{7}{|l|}{ Firm characteristics } \\
\hline ROA & 0.032 & 0.142 & 0.054 & 0.097 & 0.052 & 0.059 \\
\hline Firm size (m. \$) & $3,268.493$ & $7,566.557$ & 25.917 & 217.820 & 61.035 & 340.141 \\
\hline Firm growth ${ }^{\mathrm{a}}$ & 1.005 & 0.008 & 1.047 & 0.057 & 1.055 & 0.051 \\
\hline Market share (\%) & 3.229 & 8.056 & 2.155 & 8.587 & 2.630 & 31.981 \\
\hline Short-term risk & 0.684 & 0.603 & 1.108 & 1.931 & 0.835 & 0.756 \\
\hline Gearing & 1.298 & 9.698 & 1.397 & 3.718 & 1.332 & 3.258 \\
\hline \multicolumn{7}{|c|}{ Industry characteristics } \\
\hline HHI & 0.126 & 0.099 & 0.148 & 0.257 & 0.032 & 0.067 \\
\hline Industry size (bn. \$) & 20.344 & 17.333 & 6.570 & 7.809 & 7.333 & 7.267 \\
\hline Industry growth ${ }^{\mathrm{a}}$ & 0.983 & 0.077 & 1.032 & 0.022 & 1.026 & 0.016 \\
\hline
\end{tabular}

Size class distribution (no. of firms and $(\%))^{b}$

$\begin{array}{lrrr}\text { Large } & 84(84.0) & 128(3.6) & 123(8.82) \\ \text { Medium } & 11(11.0) & 305(8.6) & 285(20.4) \\ \text { Small } & 5(5.0) & 824(23.3) & 674(48.3) \\ \text { Micro } & 0(0.0) & 2,284(64.5) & 313(22.4)\end{array}$

Firm variables: ROA = operating profit/total assets; Firm size = total assets; Firm growth = yearly growth rate of total assets; MS = firm sales/subsector sales; Short-term risk = current liabilities/current assets; Gearing = non-current liabilities/shareholder funds

Industry variables: HHI: Herfindahl-Hirschman index for each NACE sector in the EU sample; Industry size = value of sales of NAICS/NACE industry; Industry growth = yearly growth rate of value of sales.

Source: Own calculations based on AMADEUS, Eurostat (2014), Compustat and USDoC (2014).

${ }^{a}$ Average growth rates are calculated using geometric means. 
${ }^{\mathrm{b}}$ To assure comparability both the EU and the US firms are assigned to size classes based on the SME definition of the European Commission (2005): Micro: total assets $<\$ 2.63$ million; Small: total assets $<\$ 13.14$ million; Medium: total assets $<\$ 56.51$ million. Firms are assigned to these size classes based on their total assets in the first available year In order to convert $€$-values into US\$ we use the exchange rate of Aug. $29^{\text {th }} 2014=0.76(€ / \$)$.

Table 3. Dynamic panel model estimation results

\begin{tabular}{|c|c|c|c|c|c|c|}
\hline \multirow[b]{2}{*}{ Variables } & \multicolumn{2}{|c|}{ GMM } & \multicolumn{2}{|c|}{ OLS } & \multicolumn{2}{|c|}{ GMM } \\
\hline & US & $\begin{array}{c}\text { EU-5 } \\
\text { (matched) }\end{array}$ & US & $\begin{array}{c}\text { EU-5 } \\
\text { (matched) }\end{array}$ & $\begin{array}{c}\text { US } \\
\text { excluding } \\
2008 / 09\end{array}$ & $\begin{array}{c}\text { EU-5 } \\
\text { (matched) } \\
\text { excluding } \\
2008 / 09\end{array}$ \\
\hline$\pi_{\mathrm{i}, \mathrm{t}-1}$ & $\begin{array}{c}0.293 \\
(1.90) *\end{array}$ & $\begin{array}{c}0.340 \\
(1.71)^{*}\end{array}$ & $\begin{array}{c}0.608 \\
(8.12)^{* * *}\end{array}$ & $\begin{array}{c}0.631 \\
(35.00)^{* * * *}\end{array}$ & $\begin{array}{c}0.360 \\
(1.94) *\end{array}$ & $\begin{array}{c}0.372 \\
(1.77)^{*}\end{array}$ \\
\hline Firm size & $\begin{array}{c}0.011 \\
(2.29) * *\end{array}$ & $\begin{array}{c}0.002 \\
(1.98)^{* *}\end{array}$ & $\begin{array}{c}0.007 \\
(3.23)^{* * *}\end{array}$ & $\begin{array}{c}0.001 \\
(2.90)^{* * * *}\end{array}$ & $\begin{array}{c}0.011 \\
(2.21)^{* *}\end{array}$ & $\begin{array}{c}0.002 \\
(1.88)^{*}\end{array}$ \\
\hline Firm growth & $\begin{array}{l}0.379 \\
(1.36)\end{array}$ & $\begin{array}{l}0.001 \\
(0.26)\end{array}$ & $\begin{array}{l}0.319 \\
(1.34)\end{array}$ & $\begin{array}{l}0.000 \\
(0.97)\end{array}$ & $\begin{array}{l}0.134 \\
(0.61)\end{array}$ & $\begin{array}{l}0.000 \\
(0.01)\end{array}$ \\
\hline Market share & $\begin{array}{l}0.000 \\
(0.07)\end{array}$ & $\begin{array}{l}0.003 \\
(1.01)\end{array}$ & $\begin{array}{l}0.000 \\
(0.01)\end{array}$ & $\begin{array}{l}0.000 \\
(0.48)\end{array}$ & $\begin{array}{l}-0.000 \\
(-0.26)\end{array}$ & $\begin{array}{l}0.003 \\
(1.43)\end{array}$ \\
\hline Short-term risk & $\begin{array}{c}-\mathbf{0 . 0 4 1} \\
(-3.00)^{* * *}\end{array}$ & $\begin{array}{c}-0.024 \\
(-1.71)^{*}\end{array}$ & $\begin{array}{c}-0.032 \\
(-3.24)^{* * * *}\end{array}$ & $\begin{array}{c}-0.004 \\
(-6.38)^{* * * *}\end{array}$ & $\begin{array}{c}-0.040 \\
(-3.02)^{* * *}\end{array}$ & $\begin{array}{c}-0.022 \\
(-1.78)^{*}\end{array}$ \\
\hline Gearing & $\begin{array}{c}0.001 \\
(2.99) * * *\end{array}$ & $\begin{array}{l}0.000 \\
(0.11)\end{array}$ & $\begin{array}{c}0.001 \\
(1.94) *\end{array}$ & $\begin{array}{c}-0.000 \\
(-5.41)^{* * *}\end{array}$ & $\begin{array}{l}0.000 \\
(1.07)\end{array}$ & $\begin{array}{l}0.000 \\
(0.04)\end{array}$ \\
\hline HHI & $\begin{array}{l}0.000 \\
(0.92)\end{array}$ & $\begin{array}{c}0.041 \\
(3.27)^{* * * *}\end{array}$ & $\begin{array}{l}0.000 \\
(0.58)\end{array}$ & $\begin{array}{c}0.022 \\
(4.54) * * *\end{array}$ & $\begin{array}{l}0.000 \\
(0.68)\end{array}$ & $\begin{array}{c}0.037 \\
(3.31)^{* * *}\end{array}$ \\
\hline Industry size & $\begin{array}{l}-0.000 \\
(-1.45)\end{array}$ & $\begin{array}{l}0.000 \\
(0.80)\end{array}$ & $\begin{array}{l}-0.000 \\
(-0.98)\end{array}$ & $\begin{array}{l}0.000 \\
(1.57)\end{array}$ & $\begin{array}{l}-0.000 \\
(-1.03)\end{array}$ & $\begin{array}{l}0.000 \\
(0.89)\end{array}$ \\
\hline Industry growth & $\begin{array}{c}-0.025 \\
(-1.86)^{*}\end{array}$ & $\begin{array}{c}0.000 \\
(2.87)^{* * * *}\end{array}$ & $\begin{array}{c}-0.025 \\
(-2.10)^{* *}\end{array}$ & $\begin{array}{c}0.000 \\
(3.45)^{* * *}\end{array}$ & $\begin{array}{c}-\mathbf{0 . 0 3 0} \\
(-2.38)^{* *}\end{array}$ & $\begin{array}{c}0.000 \\
(3.02)^{* * * *}\end{array}$ \\
\hline Constant & $\begin{array}{l}-0.475 \\
(-1.53)\end{array}$ & $\begin{array}{l}-0.001 \\
(-0.09)\end{array}$ & $\begin{array}{l}-0.381 \\
(-1.55)\end{array}$ & $\begin{array}{l}-0.003 \\
(1.24)\end{array}$ & $\begin{array}{l}-0.230 \\
(-0.88)\end{array}$ & $\begin{array}{l}0.001 \\
(0.09)\end{array}$ \\
\hline Wald $\chi^{2}$ & $78.18 * * *$ & $88.98 * * *$ & & & $76.05^{* * *}$ & $79.58 * * *$ \\
\hline $\begin{array}{l}\text { Hansen } \chi^{2} \\
p\end{array}$ & $\begin{array}{l}21.68 \\
0.154\end{array}$ & $\begin{array}{c}2.34 \\
0.506\end{array}$ & & & $\begin{array}{l}20.18 \\
0.212\end{array}$ & $\begin{array}{c}2.05 \\
0.562\end{array}$ \\
\hline $\begin{array}{l}\text { AR(2) z-value } \\
p\end{array}$ & $\begin{array}{l}-0.69 \\
0.491\end{array}$ & $\begin{array}{c}1.49 \\
0.135\end{array}$ & & & $\begin{array}{l}-1.02 \\
0.306\end{array}$ & $\begin{array}{c}1.95 \\
0.051\end{array}$ \\
\hline $\begin{array}{l}F \\
R^{2}\end{array}$ & & & $\begin{array}{c}78.55 * * * \\
0.455\end{array}$ & $\begin{array}{c}208.34 * * * \\
0.406\end{array}$ & & \\
\hline
\end{tabular}




\footnotetext{
Dependent variable: $\pi_{\mathrm{i}, \mathrm{t}}$ (profit deviating from the mean)

Firm variables: Firm size $=$ natural logarithm of total assets; Firm growth $=$ yearly growth rate of total assets; Market share $=$ firm sales/industry value of sales; Short term risk = current liabilities/current assets; Gearing = non-current liabilities/shareholder funds.

Industry variables: HHI=Herfindahl Index of NAICS/NACE industry; Industry size = sales of NAICS/NACE industry;

Industry growth $=$ growth rate of value of sales.

Numbers in parentheses are $\mathrm{z}-\mathrm{t}$-values based on robust standard errors.

$* * *, * *, *$ significant at the $1 \%, 5 \%, 10 \%$ level, respectively.
}

\section{Appendix}

\section{Table A1. Variable definitions}

\begin{tabular}{|c|c|c|}
\hline Variables & US & $\mathbf{E U}$ \\
\hline \multicolumn{3}{|l|}{ Firm characteristics } \\
\hline Datasource & $\begin{array}{l}\text { Compustat Standard and Poor's US } \\
(\text { measured in } \$)^{\mathrm{a}}\end{array}$ & $\begin{array}{l}\text { Bureau van Dijk`s AMADEUS } \\
\text { (measured in } €) .{ }^{\mathrm{b}}\end{array}$ \\
\hline Profitability (ROA) & $\begin{array}{l}\text { Earnings Before Interests and Taxes } \\
\text { (EBIT)/Total Assets }\end{array}$ & $\begin{array}{l}\text { Earnings Before Interests and Taxes } \\
\text { (EBIT)/Total Assets }\end{array}$ \\
\hline Firm size (TA) & Total Assets (Balance sheet total) & Total Assets (Balance sheet total) \\
\hline Firm growth & $\begin{array}{l}\text { Yearly growth factor of Total Assets: } \\
\text { TA }_{t} / \mathrm{TA}_{\mathrm{t}-1}\end{array}$ & $\begin{array}{l}\text { Yearly growth factor of Total Assets: } \\
\text { TA }_{t} / \mathrm{TA}_{\mathrm{t}-1}\end{array}$ \\
\hline Firm sales & $\begin{array}{l}\text { Sales excluding discounts and allowances for } \\
\text { credit given to customers }\end{array}$ & Sales excluding stock variations and VAT \\
\hline Market share (Msh) & Firm sales/6-digit NAICS industry sales & Firm sales/4-digit NACE Industry sales \\
\hline \multirow[t]{3}{*}{ Short-term risk } & $\begin{array}{l}\text { Short Term Liabilities (STL)/Current Assets } \\
\text { (CA) }\end{array}$ & Current Liabilities (CL)/Current Assets (CA) \\
\hline & $\begin{array}{l}\text { with STL = liabilities due within one year, } \\
\text { including short-term debt and the current } \\
\text { portion of long-term debt \& }\end{array}$ & $\begin{aligned} \text { with } \mathrm{CL} & =\text { Loans due within one year } \& \\
\mathrm{CA} & =\text { Stocks }+ \text { Debtors }\end{aligned}$ \\
\hline & $\begin{array}{l}\mathrm{CA}=\text { Cash and Short-Term Investments }+ \\
\text { Inventories }+ \text { Receivables }\end{array}$ & \\
\hline
\end{tabular}




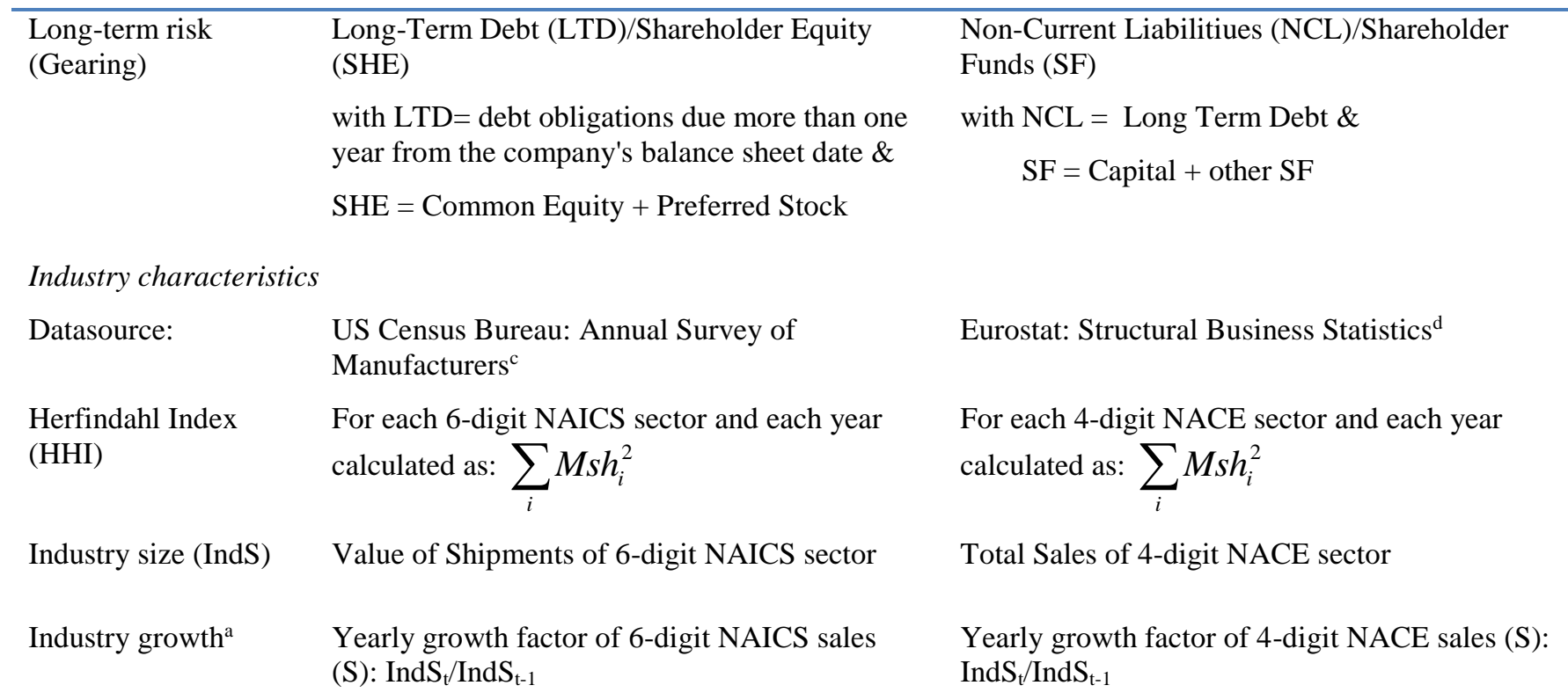

\footnotetext{
${ }^{a}$ Standard \& Poor's COMPUSTAT (North America) User's Guide Data Definitions: www.compustat.com

${ }^{\mathrm{b}}$ Further information available from the AMADEUS Internet User Guide: www.bvdep.com.

${ }^{c}$ https://www.census.gov/programs-surveys/economic-census.html

${ }^{\mathrm{d}} \mathrm{http}: / /$ ec.europa.eu/eurostat/de/data/database
} 